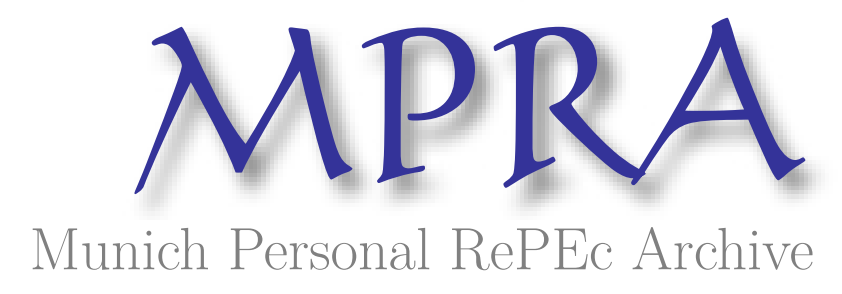

\title{
Chinese Capitalism in the OECD Mirror
}

\author{
Carney, Richard
}

14 March 2007

Online at https://mpra.ub.uni-muenchen.de/5144/

MPRA Paper No. 5144, posted 04 Oct 2007 UTC 
Draft: September 27, 2007

\title{
Chinese Capitalism in the OECD Mirror
}

\author{
Richard W. Carney* \\ iscarneyr@ntu.edu.sg
}

\begin{abstract}
As China's economy grows and matures, is it developing institutional patterns that resemble those of other wealthy countries? By examining the origins of modern capitalist institutions among wealthy countries, and how interests structured them, I draw implications for China. Specifically, I find that China resembles continental European capitalism far more than Anglo-American capitalism, and that it is likely to remain this way for the foreseeable future.
\end{abstract}

*Assistant Professor, S. Rajaratnam School of International Studies, Nanyang Technological University, Singapore. 


\section{Introduction}

As China's economy grows and matures, is it developing institutional patterns that resemble those of other wealthy countries? To answer this question, we must first identify the fundamental characteristics that differentiate capitalist economies from one another. In Varieties of Capitalism: The Institutional Foundations of Comparative Advantage, Hall and Soskice (2001), drawing on the work of Oliver Williamson (1975), point to asset specificity as a critical attribute. Where assets are specific to the goods and services that are produced, relationships tend to dominate the manner in which actors organize their economic activity. They call this kind of capitalist system a Coordinated Market Economy (CME). Countries falling into this category include many of the continental European nations, such as Austria, Belgium, Denmark, Finland, Germany, Norway, Sweden, and Switzerland, as well as Japan. Where assets are more general -that is, they can more easily be switched from producing one kind of good or service to another - arms-length interactions predominate. This type of capitalist system is called a Liberal Market Economy (LME), and it is found in the UK, US, Ireland, Canada, and Australia.

Within these two categories, several features of political economies complement one another, including education and training, innovation, employment, wages, fiscal and monetary policy, corporate governance, and the structure of the financial system. As one moves toward the CME end of the spectrum, education and training tends to be more specialized and geared towards the particular industries into which students will become employed, innovations tend to occur incrementally and primarily within well-established industries, employment and wages are more stable, fiscal policy is more redistributive (and income inequality and poverty levels are lower), monetary policy has more of an inflationary bias to promote higher employment, corporate governance tends to be more concentrated in the hands of a few owners, and the 
financial system relies more heavily on banks. Where assets are specific to the goods and services that are produced, relationships tend to dominate the manner in which actors organize their economic activity, as in CMEs. Where assets are more general -- that is, they can more easily be switched from producing one kind of good or service to another -- arms-length interactions predominate, as in LMEs.

However, Hall and Soskice acknowledge that several countries do not fit neatly onto their CME-LME continuum. They place these political economies into a third category: Mediterranean (or Mixed) Capitalism. They are distinguished by their recent histories of extensive state intervention and large agrarian sectors, as in Italy, France, Spain, Portugal, Greece, and Turkey (Hall and Soskice, 2001: 21). Thus, taken together, Hall and Soskice identify three key attributes that distinguish capitalist systems from one another: asset specificity, the level of government intervention, and the importance of the agrarian sector.

Actors representing the key factors of production - land, labor, and capital - have a major stake in how institutions manifest these attributes. The coalitions that form among these actors, and who wins the political battles that ensue, is the determining factor for the structure of the capitalist system. And the outcomes of political battles that occur at critical junctures of institutional change matter most. Insofar as this perspective enables us to understand the origins of capitalist institutions among OECD countries, we can draw implications for China.

My analysis is related to work done by scholars who examine how interests and institutions affect financial outcomes. The argument, however, differs from those who consider coalitional conflicts among managers, owners, and labor (Gourevitch and Shinn, 2005), the effects of decentralized politics (Verdier, 2003), those who emphasize social welfare politics (Roe, 2003), or legal system effects (La Porta, Lopez-de-Silanes, Shleifer, and Vishny, 1998) 
and those who focus on the consequences of development in combination with international trade and capital flows (Rajan and Zingales, 2003).

The paper is organized into the following sections: finance as a proxy for capitalism; actors and their preferences; coalitions and capitalist outcomes; historical patterns; cases: France and Japan; implications for China; and conclusions.

\section{Finance as a Proxy for Capitalism}

Because capitalist systems are complex, the analysis would be more tractable if it were possible to focus on a single sphere of the political economy that could serve as a useful indicator for the structure of the broader capitalist system. By what criteria should we choose this sphere? First, it would have to vary along the three key dimensions identified by Hall and Soskice: asset specificity, government intervention, and the size of the agrarian sector. Second, it should exhibit strong complementarities to other dimensions of the political economy. Third, it would be helpful if data were available across countries and time. These three qualifications make the financial system particularly attractive.

The first key dimension, asset specificity, gets reflected quite well in the structure of the financial system. With a greater reliance on general assets, and arm's-length interactions, securities markets tend to be more important; LMEs tend to have a higher market capitalization than CMEs (Hall and Soskice, 2001: 19). Government intervention in the economy also gets straightforwardly reflected in the structure of the financial system by the extent of government ownership of the nation's banks. Indeed, development economists point to government ownership of banks as a, if not the, critical mechanism by which government intervention in the 
economy takes place. ${ }^{1}$ The importance of the agrarian sector also gets reflected in the structure of the banking system, primarily through the scope of agricultural banking. A larger agrarian sector, and the size of financing directed to it, reflects its importance.

\section{Actors and Their Preferences}

Because of their fundamental importance to the structure of any nation's economy, their political power during industrialized nations' institutional birth and evolution, and because they have strong interests in the structure of the financial system (and the broader capitalist system), actors representing land, labor, and capital are examined. What are the preferences of these actors with regard to the three capitalist attributes?

Land (farmers): With regard to asset specificity, farmers prefer an economy with a greater emphasis on specific assets; in other words, a relationship-based economy. Long-term economic arrangements are important to them for coping with uncertain crop yields from one season to the next. Farmers, across most countries during the twentieth century, have usually been too small to seek financing from capital markets, and so they have tended to rely on local banks, either in the form of branches of large, networked banks, or in the form of unit banks (i.e., small, local banks without ties to a larger, national banking network). This relationship to the local bank, or agricultural credit bureau, is critical to their survival and success. Hence, they likewise have a clear preference for small, local, agrarian banks. They have also tended to favor government

\footnotetext{
${ }^{1}$ Gerschenkron (1962), Hawtrey (1926), Lewis (1950), Myrdal (1968), Garvy (1977), Kornai (1979), Shleifer and Vishny (1994), Shleifer (1998), and La Porta, Lopez-de-Silanes, and Shleifer (2002).
} 
intervention in order to divert money away from industrializing sectors (where a higher return is likely).

Labor (workers): For reasons of employment stability, an economy centered around specific assets would be more favorable to labor (Aoki, 1994). With regard to corporate finance, concentrated ownership encourages the long-term employment stability that labor seeks. Concentrated ownership may occur via banks, as in Germany and Japan for many decades following World War II, or through a majority of shares being held in the hands of a few owners. Unlike farmers, however, labor tends to favor a more centralized financial system which facilitates the financing of urban industries. But like farmers, labor also favors government intervention in the economy, primarily via banks, in order to provide financing to industry during downturns in the economy to avert layoffs. If banks are not a viable option for influencing industry (i.e., securities markets are more dominant as a result of globalization), labor still favors government intervention to minimize layoffs, as frequently occurs with mergers and acquisitions. In this regard, they favor 'managed markets'.

Capital (Owners): Owners of firms face two basic external financing choices: issuing securities or taking a loan. The recent literature on corporate finance focuses on a continuum of financing instruments defined according to the elasticity of their cost with respect to problems of asymmetric information (Myers 1984; Myers and Majluf 1984; Diamond 1991). As firms mature, they ascend this 'pecking order' of finance. Firms just starting out may be forced to rely exclusively on retained earnings and the wealth of insiders. After a successful beginning, the firm can begin to rely on bank loans. The bank spends resources to monitor the firm, and protects 
itself against adverse selection problems by holding a debt claim on the firm. As the firm matures and develops a track record, its financing will change. Informed intermediaries will be willing to take equity positions in the firm, which will reduce the leverage of the firm and its exposure to financial distress, and provide a positive signal to outside investors. Outside finance through securities may initially take the form of closely held senior instruments (e.g., private

placements). Later, firms will graduate to issuing bonds and preferred and common stock on the open market to outsiders, using underwriters as a means for providing credible signals of the firm's value to outsiders.

At the same time, firms favor minimal government intervention since this reduces inefficiencies in the allocation of capital, and lowers the costs of obtaining financing (e.g., via taxes and regulations). Firms likewise favor low levels of agrarian financing so that capital gets allocated to industrializing (modernizing) sectors of the economy. But because the paper focuses on implications for China, it is important to emphasize that this preference regards privately owned firms. State-owned enterprises will tend to favor banks and government intervention since they would have to pay higher financing costs otherwise.

\section{Coalitions and Outcomes}

Farmers $(\mathrm{F})$, labor $(\mathrm{L})$, and owners of large firms $\left(\mathrm{K}_{\mathrm{L}}\right)$ do not necessarily form coalitions in favor of specific financial system outcomes; rather, they form political power-sharing coalitions from which financial and capitalist structures emerge. Table 1 illustrates the coalitions and outcomes. 
Table 1: Coalitions and Financial/Capitalist System Outcomes

\begin{tabular}{|c|c|c|c|c|}
\hline Cleavage & Winner & Financial System Outcome & $\begin{array}{c}\text { Corresponding } \\
\text { Capitalist } \\
\text { System } \\
\end{array}$ & Example \\
\hline \multicolumn{5}{|c|}{ Rural vs. Urban } \\
\hline \multirow[b]{2}{*}{$\begin{array}{l}\text { F vs. } \\
\mathrm{L} \& \mathrm{~K}_{\mathrm{L}}\end{array}$} & $\mathrm{F}$ & $\begin{array}{l}\text { - High reliance on banking } \\
\text { - Increasing government intervention } \\
\text { with industrialization } \\
\text { - High level of agricultural financing }\end{array}$ & Agrarian CME & $\begin{array}{c}\text { Early } 19^{\text {th }} \\
\text { Century U.S. }\end{array}$ \\
\hline & $\mathrm{L} \& \mathrm{~K}_{\mathrm{L}}$ & $\begin{array}{l}\text { - Concentrated (likely universal) } \\
\text { banking and/or managed markets } \\
\text { - Moderate level of government } \\
\text { intervention } \\
\text { - Low level of agricultural financing }\end{array}$ & Classic CME & $\begin{array}{l}\text { Germany } \\
\text { post-WWII }\end{array}$ \\
\hline \multicolumn{5}{|c|}{ Class Conflict } \\
\hline \multirow[b]{2}{*}{$\begin{array}{l}\mathrm{K}_{\mathrm{L}} \mathrm{VS} . \\
\mathrm{F} \& \mathrm{~L}\end{array}$} & $\mathrm{~K}_{\mathrm{L}}$ & $\begin{array}{l}\text { - High reliance on equities markets } \\
\text { - Minimal government intervention } \\
\text { - Low level of agricultural financing }\end{array}$ & $\begin{array}{l}\text { Owner-oriented } \\
\text { LME }\end{array}$ & $\begin{array}{l}\text { France pre- } \\
\text { WWII, Japan } \\
\text { pre-WWII }\end{array}$ \\
\hline & $\mathrm{F} \& \mathrm{~L}$ & $\begin{array}{l}\text { - Banking dominance via } \\
\text { concentrated banking for corporate } \\
\text { finance and decentralized agrarian } \\
\text { banking } \\
\text { - High level of government } \\
\text { intervention } \\
\text { - Moderate level of agricultural } \\
\text { financing }\end{array}$ & Mediterranean & $\begin{array}{c}\text { France post- } \\
\text { WWII }\end{array}$ \\
\hline \multicolumn{5}{|c|}{ Voice vs. Property } \\
\hline \multirow[b]{2}{*}{$\begin{array}{l}\text { L vs. } \\
\text { F \& } \mathrm{K}_{\mathrm{L}}\end{array}$} & $\mathrm{L}$ & $\begin{array}{l}\text { - High reliance on banking } \\
\text { - High level of government } \\
\text { intervention } \\
\text { - Low level of agricultural financing }\end{array}$ & Statist CME & $\begin{array}{c}\text { Austria post- } \\
\text { WWII }\end{array}$ \\
\hline & $\mathrm{F} \& \mathrm{~K}_{\mathrm{L}}$ & $\begin{array}{l}\text { - Decentralized banking with well } \\
\text { developed, diffusely owned equities } \\
\text { markets } \\
\text { - Minimal government intervention in } \\
\text { corporate finance; gov. intervention } \\
\text { for agricultural financing } \\
\text { - Moderate level of agricultural } \\
\text { financing }\end{array}$ & Managerial LME & $\begin{array}{c}20^{\text {th }} \text { Century } \\
\text { U.S. }\end{array}$ \\
\hline & & & & \\
\hline $\begin{array}{l}\text { Social } \\
\text { Contract }\end{array}$ & $\mathrm{F}, \mathrm{L}, \mathrm{K}_{\mathrm{L}}$ & $\begin{array}{l}\text { - Concentrated banking for industry } \\
\text { with extensive local agricultural } \\
\text { credit offices and/or managed } \\
\text { markets } \\
\text { - Moderate government intervention } \\
\text { - Moderate level of agricultural } \\
\text { financing }\end{array}$ & Inclusive CME & $\begin{array}{l}\text { Japan post- } \\
\text { WWII }\end{array}$ \\
\hline
\end{tabular}




\section{1) Rural vs. Urban Politics}

i) Farmers: Small, rural banks are likely to dominate when farmers wield political power. This is the first stage from which industrialization begins. As industrialization proceeds, the important question regards whether they will form a coalition with capital or labor. But of potentially greater importance is that democratic political institutions may be created when farmers wield vast political power, as in the early nineteenth century U.S. The political institutions allowed farmers to preserve their power despite a fall in their economic importance and population size. Accordingly, political authority regarding the structure of the financial system was turned over to the subnational level. Consequently, banking remained fragmented, and agrarian financing was disproportionately high.

ii) Labor and Capital Coalition: This coalition is the classic one that leads to a coordinated market economy in which a banking-oriented financial system emerges, like that found in postWWII Germany. In this case, concentrated ownership via banks permits greater employment stability for labor. At the same time, bank lending will generally be more centralized to cater to urban industries. Government intervention is also likely, albeit in a more indirect manner than that found when labor alone, or labor and farmers, exercise political control.

\section{2) Class Conflict}

i) Capital: When owners of capital -- owners of large firms in particular -- control politics, they are likely to press for the development of equities markets and to retain controlling blocks in corporations (e.g., pre-WWII France and Japan). Government intervention will be minimal, and agrarian financing will be low. Banks will be universal with branches in rural areas to draw 
deposits out of the interior and to facilitate climbing of the financial 'pecking order' (Calomiris, 2000).

ii) Farmers and Labor: This populist coalition leads to a combination of centralized commercial banking to finance industrial development and local agricultural banking, with heavy government involvement in both. What is particularly interesting about this case is the difficult transition that occurs as capital owners become more influential. Because institutions were originally designed according to the preferences of labor and farmers, they do not easily accommodate capital owners' growing influence. Consequently, growing pains occur for the political economy as its institutions adjust. Also notable of this capitalist outcome is the heavy government intervention in economy since both actors favor it.

\section{3) Voice vs. Property}

i) Labor: When labor wields exclusive political power, a centralized, government-controlled banking system emerges. Labor seeks to control the financial system through nationalized, government-run banks in order to direct lending to specific firms and industries in exchange for high and stable employment.

ii) Farmers and Capital Coalition: When farmers exercise political power in democratic governments, they implement a decentralized banking structure, which may precede the advent of capital's political power and economic importance. Once capital forms a coalition with farmers, capital requires the creation of centralized capital markets to finance industry since the banking system will likely remain decentralized. As part of farmers' general antipathy towards oligarchic capital, they seek to prevent the emergence of concentrated banking and large 
corporations, which creates political pressure for diffuse ownership. The U.S. offers a clear example of the financial structure resulting from this power-sharing coalition (e.g., Roe, 1994).

\section{4) Social Contract}

This occurs when labor, capital, and farmers come to a three-way compromise on the structure of the financial system. This is more likely to occur when a foreign power imposes its will on these actors, and thereby forces a compromise among them. The clearest example of this is American influence on post-WWII Japan. If it were not for American involvement, a labor-farmer outcome would have been likely. However, this capitalist form may arise independently of American foreign pressure. For example, globalization places pressure on smaller states to form a social contract like that found among many small European countries (Katzenstein, 1984). As capital gains increasing leverage via globalization, a transition may occur from a mixture of banking and market reliance to a greater reliance on markets, though in a more managed form than LME countries.

\section{Historical Patterns}

Data across time and space for the financial system variables that proxy for the capitalist system are consistent with this framework. Hall and Soskice (2001) use stock market capitalization relative to GDP as their indicator for a nation's reliance on markets relative to relationship-based forms of financing. This is a good measure, but it needs to be treated with caution. Stock markets are known for occasional bubbles which can last for several years and may occur across countries, making it a potentially unreliable measure if examining only one point in time. In the long-run (over decades), stock markets tend to settle around an equilibrium price level (e.g., $10 \%$ 
increase per annum for the NYSE), making it preferable to measure a country's reliance on stock markets across long periods of time to gauge a country's overall reliance on markets. At the same time, looking exclusively at stock markets only captures one half of the asset specificity variable. It would be preferable to have a measure for a nation's reliance on banks as well, such as bank deposits relative to GDP.

Table two shows the average reliance on stock markets during the pre-World War II period in comparison to the post-World War II era across countries. The ordering of countries in the postwar period, however, raises some questions with regard to the utility of the stock market capitalization measure as a reliable indicator for the LME-CME orientation of a country since some countries seem out of place, such as Switzerland (being too LME), and the USA (being too CME).

\section{Table 2. Stock Market Capitalization to GDP, Pre-WWII and Post-WWII}

\begin{tabular}{|c|c|c|c|c|c|c|c|c|c|c|c|c|c|c|c|}
\hline \multicolumn{10}{|c|}{ High } \\
(LME)
\end{tabular}

Source: Rajan and Zingales, 2003.

Table three illustrates the ratio of stock market capitalization to bank deposits. Compared to the stock market capitalization table, the country orderings seem more in line with the LME-CME expectations: the USA is appropriately LME for the post-war period; Switzerland remains on the LME side, but less so than before. Like table two, we see movement of countries along the LME- 
CME continuum from the pre- to the post-WWII era, notably Japan, France, Switzerland, and Belgium.

\section{Table 3. Ratio of Stock Market Capitalization to Bank Deposits, Pre-WWII and Post-WWII}

\begin{tabular}{|c|c|c|c|c|c|c|c|c|c|c|c|c|c|c|c|}
\hline \multicolumn{10}{|c|}{ High } \\
(LME)
\end{tabular}

Source: Rajan and Zingales, 2003.

According to the argument, the structure of modern capitalism is the result of institutional

bargains struck among actors representing an economy's factors of production. For some countries, these bargains were struck at the beginning of the twentieth century. For others, political battles fought after World War II led to the restructuring of its institutions both the constitution and their capitalist institutions (e.g., France, Germany, Austria, Italy, and Japan). Thus, it is important that we are sensitive to the period of time when actors fought their most recent and consequential political battles over nations' capitalist institutions.

How do we measure actors' power? It is notoriously difficult to accurately measure farmers' political influence across nations, so I focus on labor's political power for the quantitative tests (I assess farmers' influence in the case studies). In this regard, I use a measure compiled by Franzese (2002) which takes the average ideological value assigned to political parties by multiple expert studies, and is then weighted according to the number of cabinet posts 
held by each party. ${ }^{2}$ This variable allows us to place countries on a left-right wing political spectrum which then also accounts for the political orientation towards labor or capital (the higher the value, the more left-wing). Because the earliest measure is 1950, I extend it to the preWorld War II period. ${ }^{3}$ Thus, I derive two partisanship measures: a pre-WWII one and a post-

${ }^{2}$ The expert studies include Laver and Hunt (1992), Laver and Schofield (1990), Dodd (1976), Castles and Mair (1984), Laver and Budge (1992), Sani and Sartori (1983), Morgan (1976), Inglehardt and Klingemann (1987), Mavgordatos (1984), Bruneau and MacCleod (1986), Blair (1984), Kerr (1987), Taylor and Laver (1973), Browne and Dreijmanis (1982), and de Swaan (1973). Multiple expert studies are used to minimize the bias/subjectivity caused by relying on only one or a couple.

${ }^{3}$ To extend Franzese's measure prior to WWII, I use Dodd's (1976) ideological placement of political parties during the interwar period. I normalize his score so that it corresponds to the $0-$ 10 scale. Data on the partisan composition of government is obtained with Mackie and Rose's (1990) and Flora's (1987) data which, respectively, provide the proportion of seats in parliament held by each political party as well as the coalition parties forming a government, if a coalition occurred. Based on observation of such coalitions in the postwar period and coalitions in the interwar period where data are available (e.g., Australia), cabinet seats are generally assigned to parties according to the proportion of seats the coalition partner holds as a percentage of total coalition seats. Thus, based on the proportion of parliamentary seats each coalition party holds, we can determine the percentage of cabinet seats the party held, and then calculate the average partisan score for each government so that it corresponds to Franzese's measure. These data are available across countries for 1929, which offers a useful indicator for countries' partisanship 
WWII one, which simply updates the prewar measure with data from 1950 for five countries (Austria, France, Germany, Italy, and Japan) to reflect the partisanship levels when new institutional bargains were struck. Table 4 shows OLS regression results while controlling for legal family: common or civil law (La Porta, Lopez-de-Silanes, Shleifer, and Vishny, 1998). The relationship between partisanship and the alternative measures for countries' market reliance is generally robust across time.

Table 4: Partisanship and Stock Market Reliance

\begin{tabular}{|c|c|c|c|c|}
\hline & $\begin{array}{c}\text { DV: Pre- } \\
\text { WWII } \\
\text { Market/Bank }\end{array}$ & $\begin{array}{l}\text { DV: Pre- } \\
\text { WWII } \\
\text { Market Cap }\end{array}$ & $\begin{array}{l}\text { DV: Post-WWII } \\
\text { Market Cap/Bank } \\
\text { Deposits }\end{array}$ & $\begin{array}{l}\text { DV: Post- } \\
\text { WWII } \\
\text { Market Cap }\end{array}$ \\
\hline $\begin{array}{l}\text { Pre-WWII } \\
\text { Partisanship }\end{array}$ & \multirow[t]{2}{*}{$\begin{array}{c}-0.69 * * * \\
(-3.86)\end{array}$} & \multirow[t]{2}{*}{$\begin{array}{r}-0.13 * * \\
(-2.76)\end{array}$} & \multirow[b]{2}{*}{$\begin{array}{c}-0.22 * * * \\
(-2.78)\end{array}$} & \multirow[b]{2}{*}{$\begin{array}{c}-0.08^{*} \\
(-1.8)\end{array}$} \\
\hline $\begin{array}{l}\text { Post-WWII } \\
\text { Partisanship }\end{array}$ & & & & \\
\hline Common Law & $\begin{array}{c}-0.1 \\
(-0.16)\end{array}$ & $\begin{array}{l}-0.11 \\
(-0.64)\end{array}$ & $\begin{array}{c}1.08 * * * \\
(3.78)\end{array}$ & $\begin{array}{l}0.32^{*} \\
(1.98)\end{array}$ \\
\hline Adjusted $\mathrm{R}^{2}$ & 0.56 & 0.33 & 0.77 & 0.49 \\
\hline $\mathrm{N}$ & 13 & 13 & 15 & 15 \\
\hline
\end{tabular}

*** statistical significance at the $1 \%$ level; ${ }^{* *}$ statistical significance at the $5 \%$ level. Note: t-statistics in parentheses.

The second crucial aspect of capitalist systems - government intervention - is first tested with respect to government ownership of banks in 1970 and 1995 - before and after the privatization waves - and exhibits a statistically significant correlation to government partisanship. The alternative measure for government intervention - state control - likewise levels; indeed, many of the key bargains over the structure of modern capitalist institutions were struck during this interwar period. 
exhibits a statistically significant correlation. This latter variable offers a broader measure for government intervention since it includes state ownership of nonfinancial enterprises, and so the higher adjusted R-squared is suggestive of the importance of the bargains struck between labor and capital to the overall structure of the economy. Table 5: Partisanship at Origins of Capitalist Institutions
(post-WWII) and Government Intervention

\begin{tabular}{|c|c|c|c|}
\hline & $\begin{array}{c}\text { Gov Ownership } \\
\text { Banks } 1970\end{array}$ & $\begin{array}{c}\text { Gov Ownership } \\
\text { Banks } 1995\end{array}$ & State Control \\
\hline $\begin{array}{l}\text { Partisanship at } \\
\text { Origins of } \\
\text { Capitalist } \\
\text { Institutions } \\
\text { (post-WWII) }\end{array}$ & $\begin{array}{l}0.08 * * \\
(2.13)\end{array}$ & $\begin{array}{l}0.06 * * \\
(2.75)\end{array}$ & $\begin{array}{c}0.38^{* * * *} \\
(3.24)\end{array}$ \\
\hline Adjusted $\mathrm{R}^{2}$ & 0.2 & 0.32 & 0.4 \\
\hline $\mathrm{N}$ & 15 & 15 & 15 \\
\hline
\end{tabular}
at the $5 \%$ level.

Note: t-statistics shown in parentheses.

\section{Cases}

To draw implications for China, I briefly consider two country cases: pre- and post-WWII Japan and pre- and post-WWWII France. These cases are useful because they illustrate the consequences for the capitalist system when a crisis occurs that grants more power to labor and farmers - two of China's largest groups that currently lack political representation, but which could dramatically alter China's political economy if they were to gain political power.

\section{A) Japan, Pre-WWII: Owner-Oriented LME}

Japan's pre-war financial system was highly dependent on equity finance, which began with a privatization wave in 1880. Not until wartime financing occurred (beginning in 1937 with the 
Sino-Japanese war), did the financial system begin to change into a more concentrated, and bank dependent one (Hoshi and Kashyap, 2001). But with regard to the prewar banking system, most of the financing went to industry, rather than agriculture. Small farmers generally faced a capital shortage and had to pay high loan rates; around $9.2 \%$ in 1929 , compared with large firms' bond yields of 5.5-6\%. Thus, Japan's financial system in the pre-war era is characterized by a high reliance on securities markets, low levels of government intervention, and weak agricultural financing.

Japan's politics exhibited strong links between the rapidly growing business sector and government officials, with rural elites also wielding political influence. Political institutions entrenched power in the hands of the oligarchs who surrounded the emperor (the Genrō and the Privy Council) with some political power accorded to the upper house of the Diet (the House of Peers). These institutions kept policymaking out of the hands of popular influence (e.g., labor and small farmers), and thereby cemented the power of the elite - particularly the business elite and the wealthy bushido leaders. Consequently, they determined domestic economic policy, and ensured that owner-oriented markets dominated the structure of the financial system, with little government intervention. And, because such a small proportion of agrarian interests wielded any significant political influence, agricultural financing remained relatively low.

In the prewar period, labor had almost no influence on the financing decisions of large firms, nor on the financial system more broadly. Although labor gained some concessions during the interwar period, when it was strongest, the most significant pieces of legislation which would have legally protected labor unions, the Labor Union Bills of 1926 and 1927, were never passed by the Diet. 


\section{B) Japan, Post-WWII: Inclusive CME}

When the war with China began in 1938, a series of laws were passed to put the allocation and control of finance firmly under government control, resembling similar actions performed by other countries during WWII (e.g., France, Germany, and Italy). To this end, banks were consolidated. The 424 ordinary banks at the end of 1936 were consolidated to just 61 in 1945 with four major zaibatsu banks controlling almost half of the capital of Japan's financial institutions. $^{4}$

By the end of the war, bank-firm relationships were solidified and assigned banks dominated firms' external financing needs; capital raised on securities markets (bond markets in particular since the stock exchange had been closed) fell to a trickle. Hoshi and Kashyap (2001) find that the relations formalized by the munitions companies system of WWII (where a bank is assigned to a particular firm) lasted well into the postwar period.

It is important to note that although banks dominated financing during the war, this did not mean that Japan's postwar financial system would remain banking-oriented. In both the US and UK, banks were heavily relied upon during the war, and yet markets came to dominate shortly after the war ended. The political situation in Japan following the war was critical to allowing and even encouraging the continuance of the wartime bank-firm relations.

Labor: The labor movement surged immediately after the war, as shown in figure one. Nosaka Sanzo, a leading Communist, published "An Appeal to the Japanese People" which served as the basis for the Emancipation League (formerly the Anti-War League), founded in 1944. The League's program was couched in moderate language so as to appeal to a wide audience, but

\footnotetext{
${ }^{4}$ See Adams, 1964, 128-59; and Hoshi and Kashyap, ch. 3.
} 
among its key policy prescriptions, it advocated "maintaining and strengthening state control over banks" (Colbert, 1952: 64). The program served as the ideological basis for a large segment of the postwar labor movement. The more moderate Socialists, in 1946, proposed a system of state control of key industries (Colbert, 1952: 88), as well as the establishment of a Supreme Economic Council to determine general economic policies, subsidiary councils for each industry, and at each level of planning or supervision trade-union representatives, as well as representatives of business and government would participate. The long-term financial program of the Socialist Party called for the socialization of all banks and insurance companies, entailing the establishment of a Banking Control Committee to be headed by the Finance Minister and to be responsible for the utilization of funds. Additionally, it proposed that half of each banks' managers would be selected from among its employees (Colbert, 1952: 90). The resemblance to France's postwar Socialist policies is striking (Kuisel, 1986).

At first, American General Headquarters (GHQ) actively promoted labor unions, but as the Cold War began and the communist threat increased, GHQ modified its policies. The implementation of the Dodge Plan led to firings and layoffs on a large scale, causing the elimination of a large sector of the militant left, and to the reorganization and strengthening of oligopoly capital. Although the Dodge program involved expanding big industry and therefore employment in big industry, the reorganization was used carefully to weed out militant workers and to weaken the union movement. To retain the loyalty of the remaining workers, managers offered remaining employees lifetime employment. At the same time, the Japanese main bank system developed strongly after World War II. ${ }^{5}$ The main banks' ownership of stock in industrial

\footnotetext{
${ }^{5}$ Hoshi (1995) shows that post-war main bank relations grew directly out of the authoritative wartime allocation of defense companies to particular banks.
} 
firms expanded, making them main bank stockholder-creditors. They monitored firms, and acted as firms' main source of external financing for several decades after the war. Although this banking-oriented financial system remained out of the control of labor, it neatly matched their initiative for financing arrangements that would offer employment stability. Lifetime employment and the main bank system acted as stable complements, even if one did not induce the other.

Farmers: Following the war, several institutional mechanisms vaulted farmers to a politically powerful position, including the electoral system, universal male suffrage, the executivelegislative balance, and malapportionment.

Candidate-centered electoral systems such as Japan's multi-member district single nontransferable vote system create incentives for politicians to develop a loyal group of supporters (personal vote coalitions) by wooing them with pork in exchange for votes (Cowhey and McCubbins, 1995: 44). In Japan, farmers have benefited considerably as the key members of these local vote coalitions.

But the influence of farmers and small firms became a political reality only because Japan's postwar institutions granted significantly more power to the lower house than during the prewar era. Land redistribution vaulted farmers to a very politically powerful position following the war, and they subsequently comprised nearly half of the total electorate in 1950 .

With such an overwhelming proportion of the electorate, agricultural interests had sufficient power to elect Diet members outright and to propose and pass legislation. Farmers ensured a favorable deposit rate for themselves via the postal savings banks, and as long as economic growth remained high, they could be sure that the banks could pay that interest rate. 
This led to a high accumulation of funds for the government, which were used to finance industry via the Fiscal Investment and Loan Program, and saved these firms from diluting their ownership via share sales on the equities market and via mergers and acquisitions. In this way, farmers contributed to Japanese firms' reliance on patient capital. Of course, farmers also increased agricultural financing and bolstered government intervention in the economy.

\section{C) France, Pre-WWII: Owner-Oriented LME}

Like pre-war Japan, France's Third Republic political institutions also privileged the wealthy elite and excluded the populace from exercising real political influence. The financial system likewise exhibited a strong reliance on markets, with little government intervention, and low levels of agrarian financing.

Prior to the 1930s, France relied heavily on capital markets as the conduit by which money flowed from savers to borrowers with self-financing becoming more common during the 1930s. ${ }^{6}$ Table 6 shows the decline in stock and bond issues after WWII.

\footnotetext{
${ }^{6}$ Bank financing also experienced a change from a reliance on private banking in the 1920 s to public banking in the 1930s (Gueslin, 1992: 85).
} 


\section{Table 6: French Corporations' Stock and Bond Issues, 1900-1964}

(percent of gross domestic product)

\begin{tabular}{|c|c|c|c|}
\hline Year & Stocks & Bonds & Total \\
\hline 1900 & 2.0 & 1.8 & 3.8 \\
1913 & 2.6 & 2.9 & 5.5 \\
1924 & 3.3 & 1.2 & 4.5 \\
1929 & 5.7 & 2.6 & 8.3 \\
1930 & 3.4 & 4.4 & 7.8 \\
1949 & 0.6 & 0.3 & 0.9 \\
1954 & 0.6 & 0.8 & 1.4 \\
1959 & 1.7 & 1.4 & 3.1 \\
1962 & 1.4 & 1.2 & 2.6 \\
1964 & 1.2 & 1.0 & 2.2 \\
\hline
\end{tabular}

Source: Carré, Dubois, and Malinvaud (1975, 334)

Additionally, there was little government intervention in the economy, and agrarian financing likewise remained very low but this changed considerably after the war.

France's pre-WWII government was dominated by the parliament, comprised of the Chamber of Deputies and the Senate, with the Senate having the clear upper hand. The Senate was designed to insulate the political system from the universal suffrage of the Chamber of Deputies. Senators were elected indirectly by mayors and councilors of departmental and arrondissement assemblies, ensuring that they were elected only by the privileged. Wealthy landowners were over-represented in the Senate, and big business also wielded considerable influence through their direct financial contributions to Senators and through the growing number of wealthy industrialists. Labor, small business and small farmers had almost no influence in the upper house. Rather, their votes were important to the election of Deputies. 
Interests: From the mid-nineteenth century up to the 1930s, the national supply of credit went increasingly to firms participating in the industrial revolution (Gueslin, 1978, 29-44). ${ }^{7}$

Consequently, farmers faced rising borrowing costs. And in terms of France's overall financial system, agricultural credit constituted a small fraction of total enterprise financing.

Prior to World War I, unions and left-wing political movements had sporadic, but mostly negligible influence on firms and government. At the end of World War I, labor activity and union membership surged. On December 16, 1918 the Confederation of Workers issued a statement of the changes it sought in its Minimum Program, which formed the major themes of the interwar years. With regard to the economy, this document primarily focuses on the objective of dirigisme (Lorwin, 1954: 52-53).

After World War I, the Confederation of Business Owners was formed to represent the interests of big business to government, in reaction to the growing political influence of labor. Big business sought to ensure that the 'classical laws' of laissez-faire governed the structure of the French economy (Duchemin, 1940). This equated to ensuring that access to capital remained free from any government imposed restrictions or manipulation, such as regulations affecting access to securities markets, as well as control over lending arrangements through various credit granting facilities (i.e., banks).

\section{D) France, Post-WWII: Mediterranean Capitalism}

Socialists and conservatives had different visions for postwar France. The Socialist Program proposed comprehensive planning (and Keynesian countercyclical policies) to sustain full

\footnotetext{
${ }^{7}$ Gueslin's book, Les Origines du Crédit Agricole (1840-1914), offers a very thorough account of the formation of the Crédit Agricole.
} 
employment and economic development. Its author, André Philip, argued that in a planned economy certain producers were so important that they had to be nationalized so that the state could effectively control investment. ${ }^{8}$

The conservative neoliberal perspective was articulated best with Courtin's Program, which envisaged a "return to the market, economic freedom, and free trade" that prevailed during the Third Republic (Kuisel, 1981: 171). Ultimately, labor in alliance with farmers, would win the political battle by a wide margin and France would bolster industrial and agrarian banks, and promote high levels of government intervention.

Labor: In the immediate postwar environment, popular opinion accused big business of aiding the downfall of the French Republic. A popular election held in October 1945 confirmed the leftward swing that had taken place in the electorate. One of the first items on the agenda of the new Constituent Assembly was the nationalization of banks since credit was a critical element for reconstructing and managing the economy. The banking act that was eventually passed on December $2^{\text {nd }} 1945$ nationalized the four largest deposit banks (these held around half of all banks' assets and were the only banks with nationwide branch networks) and extended minor regulations over private investment banks. ${ }^{9}$ All representatives from the left and center voted for

\footnotetext{
${ }^{8}$ André Philip's report was published by the Parti Socialiste, Pour la Rénovation de la République, and entitled Les Reformes de Structure.

${ }^{9}$ For information on the formulation and effect of this banking legislation, see Alhadeff's six chapters on French banking in Competition and Controls in Banking (1968), Wilson's French Banking Structure and Credit Policy (1957), the France chapter by Henry Germain-Martin in
} 
it. ${ }^{10}$ The law structured French finance for the postwar period and gave the government greater influence over the course of postwar economic development by placing the volume and allocation of credit firmly under its control.

Farmers: With the new provisional government, small farmers now enjoyed political influence more closely reflecting their proportion of the population; there was no longer a Senate to block their legislative initiatives. So, between 1950 and 1963, Crédit Agricole medium and long-term loans rose from 630 million francs to 13 billion francs (INSEE, 1986). The Crédit Agricole considerably increased its services to farmers in comparison to the prewar period, in addition to offering low rates of interest and increasing the availability of credit, corresponding to farmers' far greater political power. ${ }^{11}$ As shown with the logarithmic scale in figure one, the government likewise increased substantially the level of funds directed to the agricultural sector.

Beckhart's Banking Systems (1954) and Dupont's Les Contrôle des Banques et la Direction du Crédit en France (1952).

${ }^{10} 461$ out of 494 representatives from mainland France voted for the law; 442 from the left and center, and 19 from the right; 33 on the right voted against.

${ }^{11}$ Carré, Dubois, and Malinvaud, 1975, 337. 
Figure 1: Value of Advances from the State to the Crédit Agricole (1923-1972) in million of Francs (logarithmic scale)

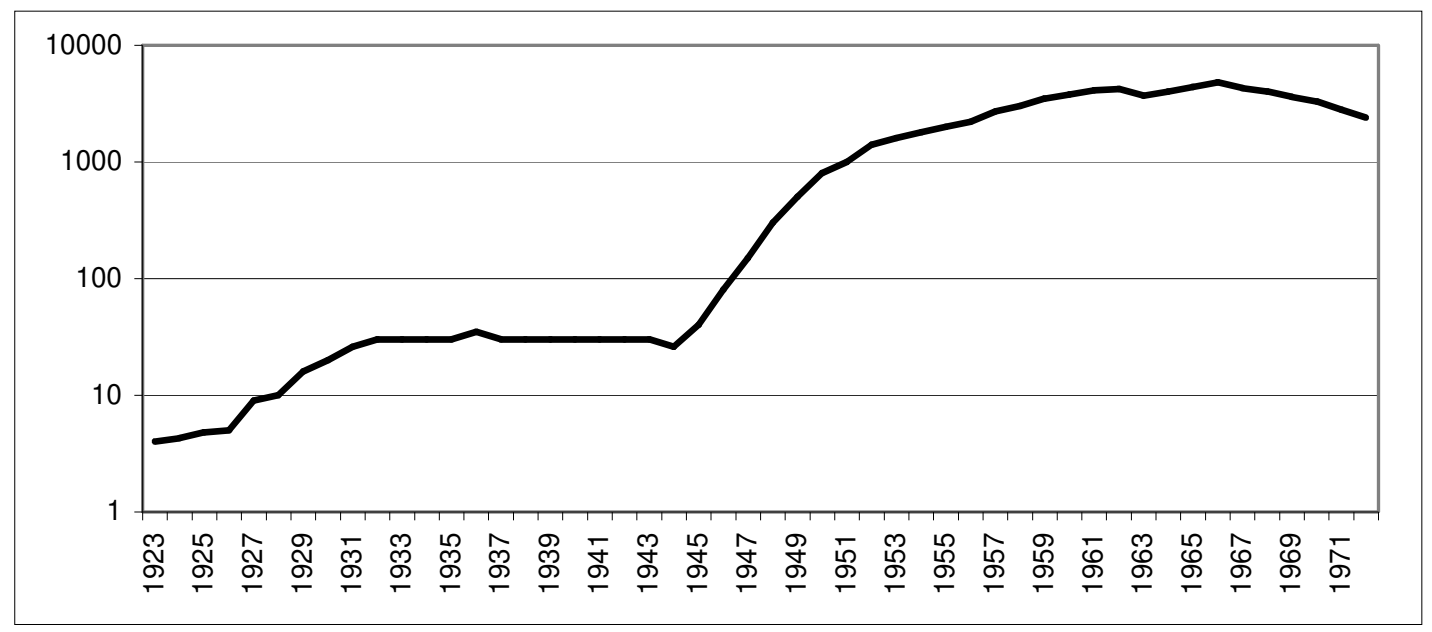

Source: adapted from Gueslin, André. 1984. Histoire des Crédit Agricoles, p. 322.

\section{Implications for China}

Based on the evidence, what are the implications for China? To answer this question, it is useful to first describe some of the key features of China's financial system and to then consider how actors could affect the government's attempts to modernize it.

The Financial System: With regard to the key dimensions of the financial system that proxy for the structure of capitalism, China is banking-dominated, has a high level of government intervention with lending disproportionately directed to wholly or partially state-owned enterprises, and there is a substantial agricultural sector comprising $60 \%$ of the population. While developing countries often exhibit many of these features, China is unusual even within this group. As compared to the level of bank intermediation in other Asian countries (45 percent in Thailand, 43 percent in India, and 37 percent in the Philippines), banks intermediate nearly 75 percent in China. And looking at the flow of funds data demonstrates that the banking sector's role is even larger, providing 95 percent of corporate funding in recent years. Indeed, as a 
McKinsey (2006) study notes, “The most striking institutional feature of China's financial system is the dominance of its banking sector." Figure 2 clearly illustrates this point.

Figure 2: China's Banking-Dominated Financial System (2004 Data)

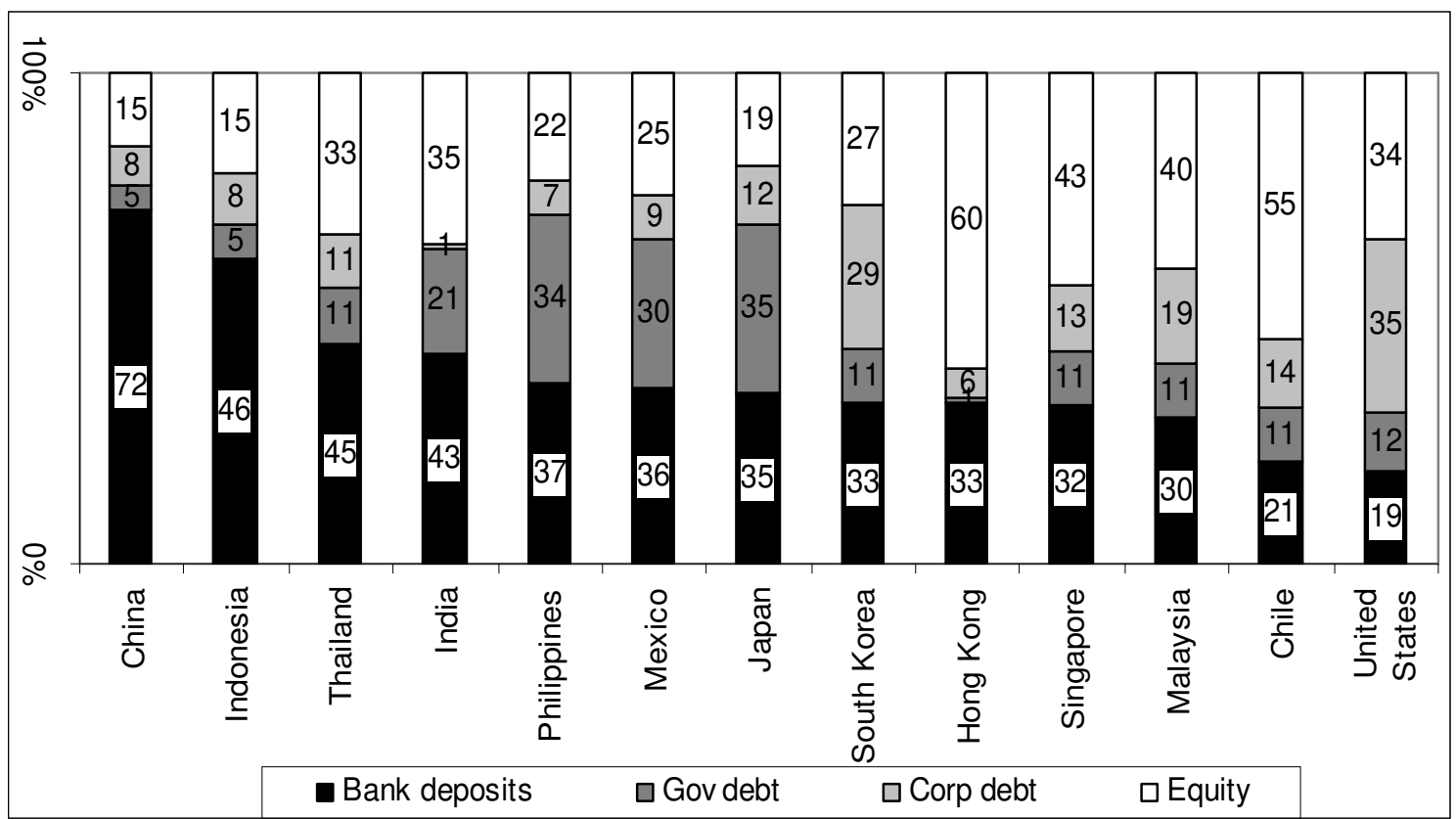

Source: McKinsey, 2006.

China's economy is more heavily reliant on banks and relationships than any of the 15 countries examined in section five has been in the twentieth century. Placing China along the same scale used to order OECD countries, as in table seven, we see that China falls at the far end of the CME side of the spectrum. 
Table 7: Stock Market Capitalization over Bank Deposits with China Included

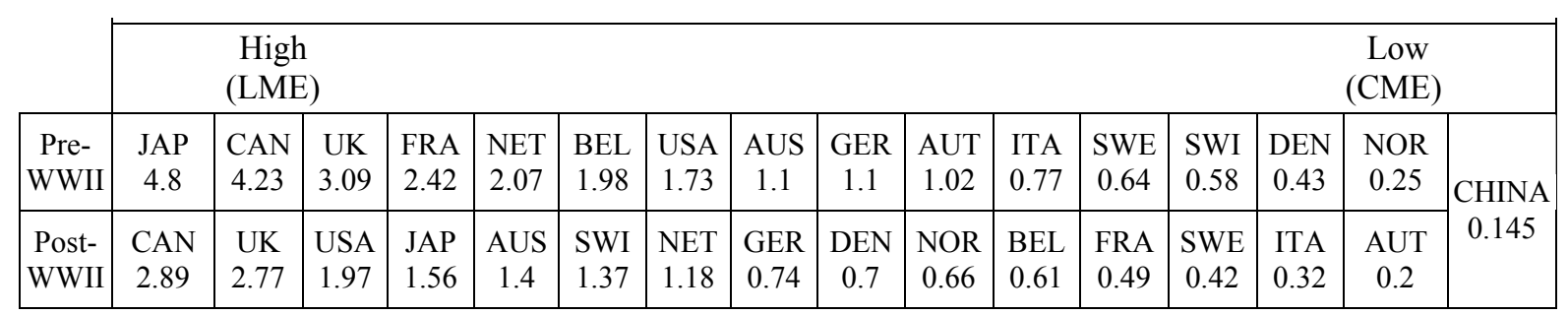

Data Source for China: McKinsey (2006).

The pre-WWII placement is particularly notable since other countries more closely resembled China's level of economic development at that time. And we can see that all but one (Switzerland) of the countries falling at the CME end of the spectrum in the pre-WWII period have remained coordinated market economies to this day. This is important to note insofar as institutional inertia preserves a country's initial institutional arrangements.

Although state ownership of firms has declined over the past 10 years, the banking system remains firmly in government hands. Indeed, China has the highest level of state ownership of banks of any major economy in the world (McKinsey, 2006). This stands in stark contrast to the experience of Eastern Europe's transitional economies and other emerging markets where privatization of the banking sector has occurred with great alacrity since 1990 . As a result, the Chinese government exerts effective control over the funds lent through the banking system since sixty percent of bank assets are held by four state-owned commercial banks: Bank of China, China Construction Bank, Industrial and Commercial Bank of China, and Agricultural Bank of China. Although the government has allowed foreign banks to purchase portions of several large banks in the past couple years, foreign ownership stakes remain small with the state still firmly in control. China also has around 120 city commercial banks and joint stock banks, as well as more than 30,000 rural and urban credit cooperatives, most of which are controlled or influenced by various levels of government. 
McKinsey offers ten recommendations to improve the financial system, many of which involve deregulating and liberalizing the banking system and capital markets. But there are likely to be considerable political obstacles to implementing these reforms. In particular, important actors in China's political economy - such as farmers, labor, owners of large firms, and the politicians who depend on these actors' acquiescence (if not their support) - are likely to have conflicting views over arms-length-oriented financial liberalization. What kind of capitalist outcome is likely based on the way China's political system mediates pressure from these actors?

Farmers: These actors (complemented by owners of small firms) favor reforms to the financial system, but they want a better banking system, not necessarily a better and larger equity market. The diversion of capital to state-owned enterprises and the lack of appropriate credit rating procedures denies them of much needed capital. As long as Chinese politicians rely on local groups to remain politically powerful, farmers (and small firms) will continue to play an important role and push for policies that divert funds away from the cities and keep finance local (Lardy, 1998). And this is consistent with local leaders' incentives. To be sure, money will go to urban areas more than before since the growth of new firms will attract financing, however, the level of financing to urban areas will not achieve its potential. To keep finance local, farmers (and local Chinese politicians who depend on their support/acquiescence) will attempt to block many of the efficiency enhancing reforms of the banking system, as witnessed in the U.S. with the McFadden and Glass-Steagall Acts. Because leaders in Beijing fear a potential farmers' rebellion, they cannot press too hard for reforms. This fear is exacerbated by the fact that farmers lack legal property rights to their land, so they have a direct interest in a democratic government that would protect property rights. And as 60 percent of the population, they would certainly gain 
from electoral democracy. At the central party meeting in 2004, the leadership called rural unrest a "life or death" issue for the party. ${ }^{12}$

Labor: Although workers and farmers lack political representation in China's government, they exercise unusual political influence because of Chinese leaders' fears of popular upheaval. Consequently, Chinese officials placate these groups while at the same time slowly shifting the economy in a market-oriented direction, and integrating it into the global economy. Doing this necessarily means moving the economy away from agriculture towards industry, and allowing unsuccessful businesses to fail, and for their workers to lose their jobs. Because of the large numbers of noncompetitive state-owned enterprises, and the potentially huge job losses, Chinese leaders have good reasons to fear a political firestorm from such maneuvers. Local politics reinforces this political pressure: "branch managers sometimes face political pressure from local government leaders to continue to supply [state-owned enterprise] funding, because this keeps the largest employers in the area afloat, and it is in the interest of both the local government and the bank itself to protect local jobs" (McKinsey, 2006: 62). At present, China's strategy seems to be to allow the economy to grow its way out of the problem, by creating enough jobs in competitive firms so that most workers do not oppose government efforts to wean companies off of state subsidized lending over time. But this strategy could be problematic since it crucially depends on maintaining high and stable levels of economic growth over a long period of time. For example, just to meet the growing demand for jobs (from graduates of college, vocational school, secondary school, ex-soldiers, rural-urban migrants, laid-off workers, and the urban

12 "Democracy in China: Civil Rights: Protests surge as reforms fail to match rising hopes," by Jonathan Watts, in Guardian International, October 11, 2005, page 17. 
unemployed), the Chinese economy must grow at least 7 percent annually, according to the former vice president of the CCP Party School Zheng Bijian (Shirk, 2007: 30). But Wu (2006) points to several potential stumbling blocks ahead for the continuance of China's high levels of economic growth, including: economic overheating, widening regional and rural-urban economic divides, banking sector fragility, environmental degradation, rampant corruption, ageing population, and military conflict with Taiwan. The very possibility of an economic slowdown places great pressure on Chinese leaders to bear workers' interests in mind when crafting policy.

Capital: While state-owned enterprises favor the continuance of directed lending via policy banks, competitive private-sector business would largely prefer liberalizing reforms that not only improve banking but also make equity markets easier to tap. Reducing the transactions costs of obtaining financing is certainly in their interest. But there are considerable obstacles to improving the banking system and securities markets, and moving the economy towards more reliance on arms-length transactions, including: (1) a high level of state ownership of Chinese banks which contributes to weak governance, lack of commercial mindset, and operational weaknesses within banks; (2) a highly decentralized banking and political structure that makes change difficult; and (3) a poorly functioning judicial system with weak legal protection for investors. Until these problems are addressed, LME-style institutions are unlikely to arise, and the non-performing loans problem and corruption will likely continue.

State ownership of banks makes it more difficult to reduce local political influence over lending decisions. It also reduces competition and lessens pressure on banks to operate on a commercial, profit-oriented basis. This is particularly true in China, where the government has injected $\$ 105$ billion into the banking system since 1998 to recapitalize banks and has engineered 
a transfer of $\$ 307$ billion of nonperforming loans to asset-management companies. Although the Chinese Banking Regulatory Commission (CBRC) has publicly stated that banks should not count on future capital injections, past actions create a situation ripe with potential for moral hazard. (McKinsey, 2006: 36).

While the level of banks' nonperforming loans has fallen from over 50\% in 1998-9 to around $21-25 \%$ at then end of 2005 , according to Standard \& Poor's, this is still considered unacceptably high by international standards. The CBRC has been charged with cleaning up NPLs by ensuring that banks meet BIS capital adequacy ratios, however, the underlying problems remain unresolved: poor corporate governance, ineffectual internal controls, and a weak credit-risk-management culture. A McKinsey report points out that many Chinese banks lack "even the most fundamental components of good corporate governance," and they further single out "poor credit-risk-management skills" as a critical issue in CBRC's ongoing efforts to overhaul Chinese banks, especially among the 120 or so smaller commercial banks and the 30,000 urban and rural credit cooperatives which account for more than half of new lending (Bekier et al, 2005). These problems have not only contributed to bad lending practices resulting in non-performing loans - but they have also led to persistently high levels of fraud. For example, just in 2005, the CBRC uncovered 'irregularities' involving 'misused funds' amounting to RMB 767.1 billion (US\$93.7 billion). But with only US\$180 million, or $0.19 \%$, of these funds being recovered, one can imagine the staggering damage inflicted on China's banking system as a result of the year after year effects of these malpractices (Wu, 2006). On top of this, the efforts to clean up banks' bad debts with asset-recovery companies have often foundered on the same cronyism and corruption that created the debt crisis. According to $\mathrm{Yu}$ Nanping, a banking expert at East China Normal University in Shanghai, "A lot of the 
management people have been taken directly from the banks ... they are disposing a lot of the bad loans they created before, and they are covering up a lot of corruption cases."13

Recently, Chinese regulators have attempted to hasten and deepen the reform process by letting foreign banks acquire stakes of up to $25 \%$ ownership of their Chinese counterparts on a highly selective basis. It is hoped that foreign banks will bring in fresh capital, cutting-edge technologies, and managerial expertise to help modernize China's antiquated banks. However, as minority shareholders, foreign banks' influence at the board-of-directors level, and hence on the corporate governance issue, will likely be limited. Improvements in this area will require strong political will.

Because of China's massive size and decentralized power structure, banking system reforms will be a long and difficult task. Among China's national banks, a good deal of autonomy remains at the branch and regional levels. And the smaller banks and cooperatives, unlikely to attract foreign investment, will be especially slow to improve. This decentralized structure makes introducing more market-oriented lending decisions difficult, because lending decisions made at the local branch level are more susceptible to influence from local government officials. While the US was able to circumvent its fragmented financial structure via the development of securities markets, China faces greater obstacles here because of the problems that arise from the state's preponderant control of banks, and its deficient judicial system.

Indeed, the biggest challenge to conquering corruption and protecting investors (particularly in an arms-length LME system) is the existence of a weak judiciary, especially at sub-national levels, which frequently fails to provide channels for victims of corruption to

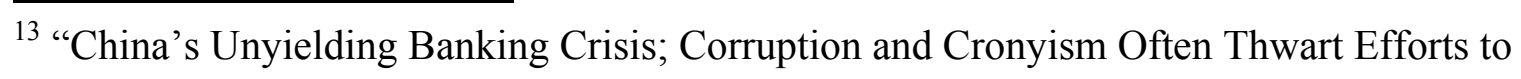
Eradicate Bad Debts,” by Peter S. Goodman, Washington Post, June 6, 2005, Section A01.
} 
address their grievances and seek redress. China's scores on the World Bank's "Rule of Law" index have slid in recent years ${ }^{14}$ in 2004 , China ranked $124^{\text {th }}$ out of 208 countries. As most of China's corrupt incidents occur at the country, township and village levels, they usually involve local officials who abuse their powers. And because these officials exercise almost absolute authority in their own domains, they also control the channels for addressing grievances.

\section{Conclusions}

China's economy can be characterized as heavily reliant on relationships. This is unlikely to change any time soon for two main reasons: (1) central government political authorities are fearful of inciting popular revolt - particularly among workers and farmers - so they continue to funnel lending to firms and individuals for politically expedient reasons; and (2) its decentralized political structure grants local leaders considerable power, including the power to decide who receives loans from the nation's policy banks. The decentralized political structure creates several additional hurdles for liberalizing reforms by: (a) undermining nationwide efficiencyenhancing reforms to the banking sector; (b) preserving corruption at the local level because of local leaders' influence over lending decisions and the lack of legal protection for investors; and (c) preventing the emergence of an effective judicial system divorced from political interference. This will lead to mutual expectations about economic interactions which will become ingrained, and institutionalized (both formally and informally), over time. As witnessed among pre-WWII OECD countries, these early patterns are unlikely to change.

\footnotetext{
${ }^{14}$ China's scores on the World Bank's "Rule of Law" index slid from -0.22 in 1998 to -0.47 in 2004. Scores for the World Bank's "Governance Indicators" range from -2.5 to +2.5 with a mean of zero. Higher negative scores correspond to poorer governance.
} 
But what if China experiences an economic downturn that leads to domestic unrest and a change of government? If democratic reforms occur, farmers will likely comprise the largest segment of the electorate (the agricultural population presently accounts for $60 \%$ of the total), and labor would form much of the rest. Under such circumstances, a coordinated market economy would likely emerge, perhaps shifting the system from its present statist model to a Mediterranean style of CME, or possibly to an inclusive CME like Japan, if capital successfully retains political influence (but the preservation of capital's political influence in Japan and Germany was due to American intervention).

Because China seems likely to retain extensive intervention in the economy, it is unlikely to evolve as the US financial system did. Indeed, Chinese leaders should not try to turn China into a US-style LME. They should instead build institutions that complement an economy centered around relationships, including specialized education and innovation systems that focus on improvements in existing technologies and focus on moving into high quality products that requires highly skilled labor as opposed to high volume, low cost production. At the same time, it needs to avoid some of the mistakes others have made. In particular, a persistently high level of government intervention, similar to France after WWII, could lead to problems for its firms down the road by creating poor intra-firm worker-manager relations, and lead to lower valueadded production (Ernst, 2003). China should likewise encourage institutional mechanisms that allow workers and managers to work together within the firm, as with codetermination in Germany. Finding ways to transition provincial rural economies away from farming to alternative kinds of small business will be difficult, but post-WWII Germany may be a useful guide here as well. 


\section{REFERENCES}

Adams, Thomas Francis Morton. (1964). A Financial History of Modern Japan. Tokyo: Research.

Alhadeff, David. (1968). Competition and Controls in Banking. University of California Press.

Allen, Franklin and Douglas Gale. (2000). Comparing Financial Systems. Cambridge, Massachusetts: MIT Press.

Aoki, Masahiko. (1994). The Japanese Main Bank System: an introductory overview. Washington: World Bank.

Beck, Thorsten, Asli Demirguc-Kunt and Ross Levine. (1999). A New Database on

Financial Development and Structure. Washington, DC: World Bank,

Development Research Group, Finance.

Blair, Antonio. (1984). The Emerging Spanish Party System: Is There a Model? West European Politics 7, no. 4: 120-55.

Browne, E. C. and J. Dreijmanis. (1982). Governmnet Coalitions in Western Democracies. New York: Longman.

Calder, Kent. (1988). Crisis and Compensation: Public Policy and Political Stability in Japan, 1949-1986. Princeton: Princeton University Press.

Carré, J. J., P. Dubois, and E. Malinvaud. (1975). French Economic Growth. Stanford, California: Stanford University Press.

Castles, Francis and Peter Mair. (1984). Left-Right Political Scales: Some 'Expert Judgments.' European Journal of Political Research 12: 73-88.

Colbert, Evelyn. (1952). The left wing in Japanese politics. New York : International Secretariat, Institute of Pacific Relations.

Commissariat à l'Intérior. (1944). "Critique de rapport sur la politique économique d'après guerre présenté par le Comité National d’Etudes de la résistance.” June, AN F 3791.

Courtin, René. (1944). Rapport sur la politique économique d'après guerre. Algiers.

Cowhey, Peter F. and Mathew McCubbins. (1995). Structure and Policy in Japan and the United States. New York: Cambridge University Press.

Dodd, Lawrence. (1976). Coalitions in Parliamentary Government. Princeton: Princeton University Press. 
Dore, Ronald. (1984). Land Reform in Japan. Continuum International Publishing Group.

Duchemin, René. (1940). Organisation Syndicale Patronale en France. Paris: Librairie Plon.

Dupeux, Georges. (1959). Le Front Populaire et Les Elections de 1936. Paris: Librairie Armand Colin.

Dupont, P. C. (1952). Le Contrôle des Banques et la Direction du Crédit en France. Paris: Dunod.

Ernst, Ekkehard. (2003). "Financial Systems, Industrial Relations, and Industry Sepcialization: An Econometric Analysis of Institutional Complementarities." Proceedings of the Oesterreichische Nationalbank Workshops, No. 1.

Franzese, Robert. (2002). Macroeconomic Policies of Developed Democracies. New York: Cambridge University Press.

Garon, Sheldon. (1987). The state and labor in modern Japan. Berkeley: University of California Press

Gaudibert, Jean Claude. (1977). Le dernier empire français. Paris: Seghers.

Gourevitch, Peter and James Shinn. (2005). Political Power and Corporate Control: The New Global Politics of Corporate Governance. Princeton University Press.

Gueslin, André. (1978). Les Origines des Crédit Agricole (1840-1914). Université de Nancy II.

Gueslin, André. (1992). Banks and state in France from the 1880s to the 1930s: the impossible advance of the banks, in Finance and Financiers in European History, 1880-1960. Cambridge: Cambridge University Press.

Hall, Peter, and David Soskice, eds. (2001). Varieties of Capitalism: the institutional foundations of comparative advantage. New York: Oxford University Press.

Henry, José-Pierre, and Marcel Régulier. (1986). Le Crédit Agricole. Paris: Presses Universitaires de France.

Hoshi, Takeo, and Anil Kashyap. (2001). Corporate Financing and Governance in Japan. Cambridge, Massachusetts: The MIT Press.

Inglehart, R. and H. -D. Klingemann. (1976). Party Identification, Ideological Preference and the Left-Right Dimensions among Western Pass Publics, in Party, Identification and Beyond: Representations of Voting and Party Competition, edited by In I. Budge, I. Crewe, and D. Farlie. London: Wiley. 
Junnosuke, Masumi. (1985). Postwar Politics in Japan, 1945-1955. University of California Press.

Kerr, H. H. (1987). The Swiss Party Systems: Steadfast and Changing, in Party Systems in Denmark, Austria, Switzerland, The Netherlands and Belgium, edited by H. Daalder. London: Pinter.

Kuisel, Richard F. (1981). Capitalism and the State in Modern France: Renovation and Economic Management in the Twentieth Century. New York: Cambridge University Press.

La Porta, Lopez-de-Silanes, and Shleifer. (2002). Government Ownership of Banks. Journal of Finance, vol. 57, 1.

La Porta, Rafael, Florencio Lopez-de-Silanes, Andrei Shleifer, and Robert W. Vishny. (1998). Law and Finance, The Journal of Political Economy, Vol. 106, No. 6., 1113-1155.

Laver, Michael and Ian Budge, eds. (1992). Party Policy and Government Coalitions. New York: St. Martin's Press.

Laver, Michael and Norman Schofield. (1990). Multipary Government: The Politics of Coalition in Europe. New York: Oxford University Press.

Lockwood, William M. (1954). The Economic Development of Japan: Growth and Structural Change, 1868-1938. Princeton: Princeton University Press.

N. Makuch, J. Peyne, and P. Prunet. (1978). Le Crédit Agricole. Paris: Berger, Levrault.

Mavgordatos, George. (1984). The Greek Party System: A Case of Limited but Polarised Pluralism, West European Politics, vol. 7, no. 4: 156-69.

McKinsey. (2006). Putting China's Capital to Work: The Value of Financial System Reform. May.

Odaka, Konosuke. (1993). 'Japanese-Style' Labour Relations, in The Japanese Economic System and its Historical Origins, Okazaki, Tetsuji and Masahiro Okuno-Fujiwara (eds.). New York: Oxford University Press.

Penn World Table 5.6 Macro Time Series. (1999).

Philip, André. (1944). Les Reformes de Structure, in Pour la Rénovation de la République. Paris: Parti Socialiste.

Rajan, Raghuram and Luigi Zingales. (2003). The Great Reversals: The Politics of Financial Development in the $20^{\text {th }}$ Century. The Journal of

Financial Economics. 
Roe, Mark. (1994). Strong Managers, Weak Owners. New York: Princeton University Press.

Roe, Mark J. (2002). Political Determinants of Corporate Governance. New York: Oxford University Press.

Sakakibara, Eisuke. (1993). Beyond Capitalism: The Japanese Model of Market Economics. New York: University Press of America.

Sani, G. and G. Sartori. (1983). Polarization, Fragmentation and Competition in Western Democracies, in Western European Party Systems, edited by H. Daalder and P. Mair. Beverly Hills: Sage.

Shleifer, Andrei. (1998). State vs. Private Ownership. Journal of Economic Perspectives, 12, $133-50$.

Shleifer, Andrei and Robert Vishny. (1994). Politicians and Firms. Quarterly Journal of Economics, 109, 995-1025.

Taylor, M. and M. Laver. (1973). Government Coalitions in Western Europe. European Journal of Political Research, I: 205-48.

Verdier, Daniel. (2002). Moving Money. New York: Cambridge University Press.

Vinen, Richard. (1991). The Politics of French Business, 1936-1945. New York:

Cambridge University Press.

Wada, Junichiro. (1996). The Japanese Election System: Three Analytical Perspectives. New York: Routledge.

Williamson, Oliver. (1983). Markets and Hierarchies: Analysis and Antitrust Implications. Free Press.

Wu, Friedrich. (2006). What Could Brake China's Rapid Ascent in the World Economy? World Economics. July, 2006. 